\title{
Persons living with AIDS in nurses' social representations: analysis of central, contranormative and attitudinal elements
}

\author{
Tadeu Lessa da Costa ${ }^{1}$ \\ Denize Cristina de Oliveira ${ }^{2}$ \\ Gláucia Alexandre Formozo ${ }^{3}$ \\ Antonio Marcos Tosoli Gomes ${ }^{4}$
}

Objectives: to describe and analyze the centrality, the mute zone and the attitudes expressed in nurses' social representations of people with Human Immunodeficiency Virus. Method: the subjects were 30 nurses from a university hospital in Rio de Janeiro. The data was collected using a Likert scale. Results: the data pointed to a process of representational change regarding Human Immunodeficiency Virus / Acquired Immunodeficiency Syndrome, with the assumption of a more positive attitude regarding living with this health issue. The hypothesis of the existence of a mute zone in the representation, comprising elements with a contranormative character, was strengthened. Conclusion: the influence of the dynamics of social normativity on how the social representations studied are expressed may contribute to a better understanding of its structuring process. It also helps in the analysis of possible gaps among the nurses' discourses and practices in relation to Human Immunodeficiency Virus / Acquired Immunodeficiency Syndrome.

Descriptors: Acquired Immunodeficiency Syndrome; Professional Practice; Attitude of Health Personnel; Nursing; Social Psychology.

${ }^{1}$ PhD, Professor, Universidade Federal do Rio de Janeiro - Campus Macaé, Brazil.

2 PhD, Full Professor, Faculdade de Enfermagem, Universidade do Estado do Rio de Janeiro, Brazil.

${ }^{3}$ Doctoral Student, Universidade do Estado do Rio de Janeiro, Brasil. Professor, Universidade Federal do Rio de Janeiro - Campus Macaé, Brazil.

${ }^{4} \mathrm{PhD}$, Professor, Universidade do Estado do Rio de Janeiro, Brazil. 


\title{
Pessoas com HIV/Aids nas representações sociais de enfermeiros: análise dos elementos centrais, contranormativos e atitudinais
}

Objetivos: descrever e analisar a centralidade, a zona muda e as atitudes expressas nas representações sociais de enfermeiros, acerca da pessoa com vírus da imunodeficiência humana. Método: os sujeitos foram 30 enfermeiros de um hospital universitário do Rio de Janeiro. Os dados foram coletados utilizando escala tipo Likert. Resultados: os resultados indicaram um processo de mudança representacional sobre o vírus da imunodeficiência humana/síndrome da imunodeficiência adquirida, com a assunção de atitude mais positiva sobre a convivência com esse agravo. Foi reforçada a hipótese da existência de zona muda na representação composta por elementos de caráter contranormativo. Conclusão: a influência da dinâmica de normatividade social sobre o modo de expressão das representações sociais estudadas pode contribuir para melhor compreensão do seu processo de estruturação. Auxilia, também, na análise de eventuais defasagens entre os discursos e as práticas dos enfermeiros em relação ao vírus da imunodeficiência humana/síndrome da imunodeficiência adquirida.

Descritores: Síndrome de Imunodeficiência Adquirida; Prática Profissional; Atitude do Pessoal de Saúde; Enfermagem; Psicologia Social.

\section{Personas con HIV/SIDA en las representaciones sociales de enfermeros: análisis de los elementos centrales, contra normativos y actitudinales}

\begin{abstract}
Objetivos: describir y analizar la centralidad, la zona muda y las actitudes expresas en las representaciones sociales de enfermeros acerca de la persona con Virus de la Inmunodeficiencia Humana. Método: los sujetos fueron 30 enfermeros de un hospital universitario de Rio de Janeiro. Los datos fueron colectados utilizando escala tipo likert. Resultados: indicaron un proceso de cambio representacional sobre el Virus de la Inmunodeficiencia Humana/Síndrome da Inmunodeficiencia Adquirida, con la Asunción de actitud más positiva sobre la convivencia con éste agravo. Fue reforzada hipótesis de existencia de zona muda en la representación compuesta por elementos de carácter contra normativo. Conclusión: la influencia de la dinámica de normatividad social sobre el modo de expresión de las representaciones sociales estudiadas puede aportar para una mejor comprensión de su proceso de estructuración. Auxilia, también, en el análisis de eventuales desfases entre los discursos y las prácticas de los enfermeros con relación al Virus de la Inmunodeficiencia Humana/Síndrome da Inmunodeficiencia Adquirida.

Descriptores: Síndrome de Inmunodeficiencia Adquirida; Práctica Profesional; Actitud del Personal de Salud; Enfermería; Psicología Social.
\end{abstract}

\section{Introduction}

The epidemic of Human Immunodeficiency Virus (HIV) and the disease it causes, Acquired Immunodeficiency Syndrome (AIDS) are a major concern for public health. There are, approximately, 33.3 million people infected with the virus in the world, with 2.6 million new cases in 2009(1). In Brazil, in 2009, 11,815 deaths from this were calculated, with an estimate of 592,914 cases of AIDS by June $2010^{(2)}$.

The question of HIV/AIDS consists, essentially, in an exceptional social fact in Western societies. This is because it has triggered a worldwide process around a disease: it has brought highly archaic categories of social thinking, such as contagion, back to the public space, with vigor; and it has driven the development of research on the issue in specific and socially labeled circles $^{(3)}$.

Thus, over the evolution of this epidemic, various metaphors have arisen, associated with AIDS, such as: death; horror; crime; punishment; a disease which affects others; war; shame; and pollution ${ }^{(4)}$. The epidemic and its respective meanings have also affected the health services and health professionals, among whom the nurses stand out. This is because nursing's fields of knowledge and care practices have specific characteristics, relating to the physical and relational proximity nurses have with the people cared for, 
which impresses on the profession particular tensions expressed in approximation to or distancing from the subjects of care depending on the context in which this care takes place ${ }^{(5)}$.

From this it may be understood that the social representations elaborated by nurses on the illness and its carriers may influence the development of the care relationships. Thus, some studies describe the contradictions in the representations of the care given to these clients, care described by the health professionals as identical to that given in the case of other pathologies - but with a concern about contamination in technical procedures and the adoption, sometimes to an excessive degree, of measures of self-protection upon discovery of the patients' seropositive status ${ }^{(6)}$.

The social representations may be defined as a form of knowledge, socially defined and shared, with a practical objective, and which contribute to the construction of a reality common to a social $\operatorname{set}^{(7)}$, embracing three spheres: subjective; inter-subjective and transubjective ${ }^{(8)}$. They entail taking symbolic positions, organized in different ways, in opinions, attitudes and stereotypes, according to their overlap in distinct social relationships ${ }^{(9)}$.

Interwoven in this concept is the dimension of attitudes, conceived of as dispositions inscribed in the subject, resulting from the objectivization of a social representation. At the same time, there is greater emphasis on the process of anchoring of the representation, through the association between the psychological and social dimensions. In this way, studying the anchoring of the attitudes in the social relationships which create them means studying them as social representations ${ }^{(9)}$.

From this perspective, this study has the following as its guiding questions: for nurses, which representational elements are probably central or of the mute zone in the social representations of the person living with HIV/AIDS? Which aspects are expressed in the attitudinal dimension, in such representations held by these professionals? The following are defined as objectives: to describe and analyze the centrality, the mute zone and the attitudes expressed in nurses' social representations concerning the person living with HIV/ AIDS.

\section{Method}

This is a quantitative, descriptive study based in the structural approach of the theory of social representations ${ }^{(10-11)}$. The study was undertaken in 2007 in two phases, considering the pluri-methodological approach. It was submitted to the Research Ethics Committee and approved under protocol no_1.650-CEP/ HUPE.

In the first phase, which had an exploratory character, 150 nurses employed at a university hospital in the municipality of Rio de Janeiro were included, in a nonprobabilistic manner for convenience, which consisted of a convenience sample of $83.3 \%$ of the universe. These subjects responded to a socio-economic questionnaire and to the technique of free word association with the inductive cue "HIV/AIDS carrier", in relation to which they produced spontaneously a maximum of five words or expressions. Afterwards, the terms produced were hierarchized by the deponents ${ }^{(12)}$. This application was termed the normal situation of collection.

Next, the technique of substitution was applied, in which the nurses were invited to produce, again, five words/expressions with hierarchization for the same inductive cue, but as if they were "people in general", in an attempt to reduce the normative pressures on the deponents and allow the evocation of elements which might be considered contranormative or politically incorrect. Such elements constitute a mute or concealed zone in a specified social representation(12). This application was termed the proxy or contranormative situation of collection.

In the analysis of the free associations using the technique of the Four Quadrant technique, arising from the first phase, it was possible to identify as probable elements of the central system in the representation in question in the normal situation: care with professional caution; health education; and treatment. In addition to this, the following peripheral elements stood out because of the importance attributed to them by the subjects: help; control of the illness; hope; family; medications; prevention; and solidarity. Also emphasized on the periphery were: prejudice; suffering; fear; discrimination; and (biological) effects of $\operatorname{AIDS}^{(12-13)}$.

For the proxy situation, in which the contranormative content has a greater chance of appearing, the following were identified as probable central elements: fear; prejudice; and homosexuality. Because of the importance attributed to them by the deponents, the following cognitions may be indicated: contamination; contagion; disease; sexual practices. Considering the possible mute zone in the representation in question, the following cognitions may be characterized for their 
potential for contranormativity: homosexuality, fear, sexual practices: and, with less emphasis, promiscuity, death and drug use(12-13).

The second stage of the research, with $20 \%$ of the initial sample, that is, 30 nurses, was started based on these results. This last sample's definition was, equally, of the non-probabilistic type, for convenience. The second stage's procedures, therefore, were the base for the present study. Thus, instruments for examining centrality in a specified social representation were constructed based on the analysis of the free associations. In the light of studies on the mute zone in social representations, these instruments included a Likert scale ${ }^{(14)}$.

The above-mentioned scale permitted the more specific exploration of the attitudinal dimension in the representations. Thus, it had: 21 items, distributed among neutral (descriptive), with positive and negative values for the object studied; and six points, with the following possibilities for positioning: totally disagree; disagree; partially disagree; partially agree; agree; and totally agree. The responses, initially, made up a database and tables, with distribution of simple and relative frequencies.

For the analysis, it was sought to organize the data so as to permit interpretation according to the logic of a Characterization Questionnaire ${ }^{(10,13)}$. For this, the following grouping of responses was created: disagree totally and disagree, considered the least characteristic aspect of the representation; partially disagree and partially agree, understood as intermediate; and agree and totally agree, denoting the item considered the most characteristic for the representation of the object in question.

The criteria used for the interpretation of the results consisted of the classification of the statements presented among the three categories: most characteristic, intermediate and least characteristic, according to the concentration of the positions in the responses of the majority of the subjects. For the strengthening of the centrality of a specified element of the social representation in question, it was considered necessary for it to be defined as most characteristic by $50 \%$ or more of the subjects ${ }^{(10,13)}$. To this end, tables with absolute and relative frequencies were constructed, with the help of the SPSS 17.0 software.

\section{Results}

In relation to the socio-professional characterization of the subjects, $86.7 \%$ were female; $63.3 \%$ were living with a partner; the average monthly income was $\mathrm{R} \$$ $4,500.00$ ( $s d \pm 1,500)$; the predominant age range was 40 to 49 years $(70 \%)$; the average time since qualification was 20 years ( $s d \pm 5) ; 90 \%$ had completed specialization and $10 \%$ had done this in infectious/ parasitic diseases; the majority (70\%) stated that when they cared for clients with HIV/AIDS, there was physical and verbal contact in the activities performed; and $76.7 \%$ stated that they had not participated in courses/ training on HIV/AIDS.

Among the statements made, nine were considered by the study's subjects to be characteristic of the person living with HIV/AIDS. These are shown in Table 1.

Table 1 - Statements considered to be "most characteristic" of the social representation of the HIV/AIDS carrier. Rio de Janeiro, Brazil, 2007

\begin{tabular}{|c|c|c|c|c|c|c|c|c|}
\hline \multirow{2}{*}{$\begin{array}{l}\text { Statements considered most characteristic by the } \\
\text { subjects }\end{array}$} & \multicolumn{2}{|c|}{ Less characteristic } & \multicolumn{2}{|c|}{ Intermediate } & \multicolumn{2}{|c|}{ More characteristic } & \multicolumn{2}{|c|}{ Total } \\
\hline & $n$ & $\%$ & $n$ & $\%$ & $n$ & $\%$ & $n$ & $\%$ \\
\hline The family is important for the HIVIAIDS carrier & 0 & 0 & 1 & 3.3 & 29 & 96.7 & 30 & 100 \\
\hline They need support and help & 0 & 0 & 1 & 3.3 & 29 & 96.7 & 30 & 100 \\
\hline There are many carriers of HIVIAIDS in Brazil & 0 & 0 & 2 & 6.6 & 28 & 93.4 & 30 & 100 \\
\hline They always need to receive a lot of tenderness & 0 & 0 & 4 & 13.3 & 26 & 86.7 & 30 & 100 \\
\hline They can control their illness with the treatment & 1 & 3.3 & 4 & 13.3 & 25 & 83.4 & 30 & 100 \\
\hline $\begin{array}{l}\text { HIVIAIDS leads to immunodepression and opportunistic } \\
\text { illnesses in its carriers }\end{array}$ & 1 & 3.3 & 5 & 16.7 & 24 & 80 & 30 & 100 \\
\hline $\begin{array}{l}\text { In caring for a carrier of HIVIAIDS, one should use personal } \\
\text { protection measures }\end{array}$ & 1 & 3.3 & 5 & 16.7 & 24 & 80 & 30 & 100 \\
\hline HIVIAIDS carriers have hope and the prospect of life & 1 & 3.3 & 7 & 23.3 & 22 & 73.4 & 30 & 100 \\
\hline HIVIAIDS carriers take a lot of medications & 1 & 3.3 & 9 & 30 & 20 & 66.7 & 30 & 100 \\
\hline
\end{tabular}

It may be noted that, in a general way, that the statements with the highest degree of agreement from the subjects are those originated based on the elements associated by the subjects in the normal situation 
of data collection. Thus, the importance of the family and of the need for support and help for the HIV/AIDS carrier, characterized in descending order through the analysis of the associations for the normal situation, were the aspects which, in the present scale, presented the highest degree of agreement among the nurses $(96.7 \%)$.

In addition to the two elements mentioned, one may add the meaning brought by the statement on tenderness in relation to the person living with HIV/ AIDS, with high agreement among the subjects (86.7\%). This aspect is also present in the analysis of the free associations in the normal situation of collection of the free associations in the first phase of the research, although with less emphasis.

The element of treatment, associated with the statement they can control their illness with the treatment obtained agreement from $83.4 \%$ of the deponents, also being shown, therefore, as a characteristic of the HIV/ AIDS carrier for the same. This cognition was presented as a probable central element in the representation, equally, through the application of the technique of free association in the normal situation, strengthening the possibility of its centrality.

Reinforcing the dimension of treatment, the majority of the deponents $(66.7 \%)$ were shown to be in agreement with the idea that HIV/AIDS carriers take a lot of medications. This aspect was least associated by the research subjects in the first phase, although it was considered important by those who made it.

In a similar way to that found by the result of the free associations in the normal conditions of collection, the statement on use of measures of personal protection in caring for patients with HIV/AIDS, obtained the agreement of $80 \%$ of the nurses. In this way, it also seems to be a prominent aspect in these professionals representations.

Another dimension to be emphasized refers to hope and prospect of life for the person living with HIV/ AIDS, with the recording of $73.4 \%$ of agreement. Along with the terms help and family appears in the contrast zone of the structure of the Four Quadrants Grid for the normal situation of collection, suggesting the existence of a subgroup of nurses with a representation whose nucleus is formed of such cognitions.

The statements there are many carriers of HIV/ AIDS in Brazil and HIV/AIDS leads to immunodepression and opportunistic illnesses in its carriers, finally, denote the incorporation of information relative to the reified universe in the analyzed representation, and point to the neutrality of the positionings.

Below, in Table 2, the statements characterized as intermediate are presented, consisting of elements which are peripheral, and, therefore, of less importance for the determination of the meaning and internal organization of the social representation.

Table 2 - Statements of the social representation of HIV/AIDS carriers considered as "intermediate". Rio de Janeiro, Brazil, 2007

\begin{tabular}{|c|c|c|c|c|c|c|c|c|}
\hline \multirow{2}{*}{ Predominantly intermediate statements } & \multicolumn{2}{|c|}{ Less characteristic } & \multicolumn{2}{|c|}{ Intermediate } & \multicolumn{2}{|c|}{ More characteristic } & \multicolumn{2}{|c|}{ Total } \\
\hline & $n$ & $\%$ & $n$ & $\%$ & $n$ & $\%$ & $n$ & $\%$ \\
\hline They are people who give great value to life & 1 & 3.3 & 24 & 80 & 5 & 16.7 & 30 & 100 \\
\hline In a general way, HIVIAIDS carriers tend to isolate themselves & 3 & 10 & 23 & 76.7 & 4 & 13.3 & 30 & 100 \\
\hline They rely on people's solidarity & 3 & 10 & 23 & 76.7 & 4 & 13.3 & 30 & 100 \\
\hline They live with suffering & 1 & 3.3 & 20 & 66.7 & 9 & 30 & 30 & 100 \\
\hline They have or have had many sexual partners & 13 & 43.4 & 16 & 53.3 & 1 & 3.3 & 30 & 100 \\
\hline They acquire the virus and the disease through sexual activity & 14 & 46.7 & 15 & 50 & 1 & 3.3 & 30 & 100 \\
\hline They are discriminated against, including in hospital & 2 & 6.7 & 15 & 50 & 13 & 43.3 & 30 & 100 \\
\hline They represent a source of contamination for other people & 13 & 43.3 & 14 & 46.7 & 3 & 10 & 30 & 100 \\
\hline
\end{tabular}

The statement with the highest concentration of responses from the deponents in the intermediate mode refers to the presentation of carriers of HIV/AIDS as people who give great value to life, with $80 \%$. Although this aspect has not featured in the Four Quadrants Grid of the first phase of the research, it was included for a better understanding of the subjects' conception of the relationship between the person with HIV/AIDS and the experience of living with the disease.

The association between people with HIV/AIDS and social isolation, which emerged on the periphery of the representation through the analysis of the associations in a proxy situation, was shown to be in an intermediate position for the nurses (76.7\%). It is worth 
highlighting that this aspect consists in the conception that the carriers of the disease avoid social contact, and, therefore, in a meaning which is inverse to that of people's distancing themselves from the carriers, that is, of discrimination. A considerable proportion of the subjects $(43.3 \%)$ showed a tendency to agree with the statement in question. In its turn, solidarity in relation to seropositive people also presented a lower importance for determining the meaning of the representation, given its intermediate position (76.7\%).

The statement relating to the experience of people with HIV/AIDS of living with suffering showed localization in the structure of the representation similar to that found through the technique of free association for the normal and proxy situations, that is, in the first periphery for the first case and in the second for the last.

In relation to discrimination, identified in the first periphery, most important in the analysis of associations for both the normative situations the subjects' perception of the occurrence in the loci of attendance more specifically, in hospital - was also investigated. In this way, a strengthening for the peripheral position was evidenced, indicated by $50 \%$ of the subjects. However, the presence of a subgroup a little smaller (43.3\%), for which this aspect was indicated as characteristic of carriers of HIV/AIDS, was also observed.

On the other hand, the statements about the acquisition of HIV through sexual practices and regarding the involvement of people with HIV/AIDS with many sexual partners presented, respectively, $50 \%$ and $53 \%$ of the deponents as having an intermediate positioning. In addition, for these two statements, subgroups of nurses ( $46.7 \%$ and $43.4 \%$ ) who expressed disagreement on this aspect were recorded.

It is thought that this data, added to that from the analysis of the free association for the proxy situation and to the aspects of the sexual practices and of homosexuality, present the possibility of strengthening the hypothesis of a mute zone regarding such elements. This may be corroborated by the fact that a prominent subgroup (50\%) of subjects expressed an intermediate position on discrimination in the hospital setting; $43.3 \%$ of the deponents did this in a direct form. However, the forms of stigmatization most associated with the person living with AIDS are not confirmed by these same subjects in their responses to the other items (Table 3), being, in consequence, attributed to the "other" health professionals with whom a close relationship is maintained and with whom the work space is divided.

In relation to the statement that carriers of HIV/ AIDS represent a source of contamination for other people (back check) two subgroups stand out, one corresponding to $46.7 \%$ of the subjects, which assumes, characteristically, an intermediate position; the other, with $43.3 \%$ of the same, expresses its disagreement in respect to the statement. Thus, one may say that the assuming a position of less emphasis and, even, of refutation by the deponents, indicates a more positive representation of the person with HIV/AIDS, or the possibility of strengthening the hypothesis of contamination as an additional constituent of this representation's mute zone.

Table 3, below, presents the statements considered by the majority of the study's subjects as less characteristic of the person with HIV/AIDS.

Table 3 - Statements considered "less characteristic" of the social representation of the HIV/AIDS carrier. Rio de Janeiro, Brasil, 2007

\begin{tabular}{|c|c|c|c|c|c|c|c|c|}
\hline \multirow{2}{*}{ Statements considered less characteristic } & \multicolumn{2}{|c|}{ Less characteristic } & \multicolumn{2}{|c|}{ Intermediate } & \multicolumn{2}{|c|}{ More characteristic } & \multicolumn{2}{|c|}{ Total } \\
\hline & $n$ & $\%$ & $n$ & $\%$ & $n$ & $\%$ & $n$ & $\%$ \\
\hline $\mathrm{He}$ is close to death & 25 & 83.4 & 4 & 13.3 & 1 & 3.3 & 30 & 100 \\
\hline They have, or have had, homosexual relationships & 19 & 63.4 & 9 & 30 & 2 & 6.6 & 30 & 100 \\
\hline $\begin{array}{l}\text { Dealing with carriers of HIVIAIDS creates a feeling } \\
\text { of fear }\end{array}$ & 13 & 43.3 & 12 & 40 & 5 & 16.7 & 30 & 100 \\
\hline
\end{tabular}

The idea that the person with HIV/AIDS is close to death was considered less characteristic by $83.4 \%$ of the deponents. This aspect emerged in the representation's second periphery in the analysis of the free associations for the normal situation - and also in the representation's first periphery for the proxy situation.
Another dimension evaluated as less characteristic of people with HIV/AIDS refers to their association with homosexuality (63.4\%), which is also present in the free associations as a central element for the proxy situation.

In relation to fear in dealing with HIV/AIDS carriers, present in the probable central nucleus of the analysis of 
free associations in the proxy situation, it was observed that it was considered less characteristic for this study's subjects $(43.3 \%)$ and intermediate for a subgroup a little smaller (40\%). Only $16.7 \%$ of the nurses agreed with this statement, which retains a certain similarity with the findings for the normal situation.

The results mentioned regarding fear of the person with HIV/AIDS strengthen, equally, the possibility of its figuration among the elements of the mute zone. This is the case, bearing in mind its contranormative character, above all when it is expressed by health care professionals.

The positionings in the face of the statement in a general way, they provoke a feeling of pity, have a largely homogenous distribution in the three subgroups, with $36.7 \%$ of the subjects showing agreement, $33.3 \%$, in an intermediate situation and $30 \%$, in disagreement. By such a pattern of distribution, it cannot be classified in any of the tables referring to the possibilities of structuring of cognitions in the representational structure and attitudinal disposition of the group of subjects studied.

\section{Discussion}

Regarding the subjects' position on the role of the family for people with HIV/AIDS, this represents an important space for overcoming emotional and/or social shortcomings for the same. Sometimes, however, there are obstacles to the improving of these people's quality of life, whether from the prejudice itself from their families or from the social isolation related to the stigmatization of the illness and other sociallyunacceptable behaviors which preceded it, such as the sexual orientation experienced(15).

Regarding measures for personal protection, bearing in mind the normative pressures in play at the time of data collection (hospital setting, presence of the researcher, academic work), the responses' distribution may indicate the expression of a politically correct discourse on biosafety. Moreover, some recent studies have described a negligence in the use of personal protective equipment in the routine of attending clients, even though the worker refers to their existence and importance. This, above all, in spaces with lower technological complexity(16).

The subjects' perceptions on the hope and prospect of life among carriers of HIV/AIDS as important elements deserve emphasis, considering that the symbolic construction around HIV/AIDS are associated with the idea of fatal disease. In addition, there is the aspect of social death, caused by the discrimination, with less symbolic deconstruction than physical death, concerning which the representation of the possibility of coexisting with the disease has developed(17).

Regarding social coexistence with people with HIV/AIDS, it reflects a perception that the process of stigmatization which people suffered leads them, in specific circumstances, to their reducing or even avoiding certain types of social environments, represented as potentially discriminatory ${ }^{(18)}$. Some authors ${ }^{(19)}$ include the health sector among such circles, suggesting the need to measure and intervene in this phenomenon, as it can cause harmful consequences for clients and society, with the increase of individual and social vulnerabilities to the health issue. In any case, it becomes necessary to emphasize that this element was only revealed as significant in the proxy situation, possibly because of its negative character or its association with the thinking of "others".

Taking into account nurses' perception about the occurrence of discrimination in the hospital environment, a bridge is established with the discussions of a study about the mute zone in the social representation of Roma among the French, in research carried out with the structural approach of social representations. In that investigation, where the interviewees attributed the negative aspects of the representation to "French people in general", who comprised "others" in the technique of substitution, it was reasonable for the authors to suppose the existence of an effect of attempt at transference or projection. That is to say, a hidden aspect of that social representation did not emerge when the subjects spoke for themselves, but was evidenced by the change of the normative situation, there being, moreover, a link with the representational content expressed. This was because the study's subjects, despite having given the views of the group "French people in general", in the proxy situation, being French themselves, in principle share with that group the hidden aspects of the representation $^{(20)}$.

From this perspective, the responses' distribution in the light of HIV/AIDS carriers' association with homosexuality may reflect the change of the epidemiological profile of the epidemic, in which male homosexuals have been progressively more affected ${ }^{(2)}$. On the other hand, bearing in mind the association which may still be observed between AIDS and homosexuality, and the latter's association with sexual deviance and promiscuity, one can think of the strengthening 
of the hypothesis as a part of the representation in question's mute zone, brought up by the technique of

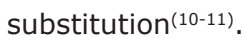

The dimension of suffering in the representation about AIDS was demonstrated by studies in the process of the social representations. Thus, the same tends to emerge in the daily life of the seropositive person as a result of: stigma, with people distancing themselves because of lack of information and fear of contagion; confrontation with the reality of the irreversibility of the disease and the anguish in the face of the possibility of death, especially in the initial period of awareness of the serological status(17).

From a perspective of temporal collation, regarding the deponents' position regarding the representational content of death, this emerged as a central and organizing element of the representation of AIDS for a similar group, in 2002(21). Given the present research's findings, which support previous works which employed a distinct method(12-13,17), one can detect the possibility of an effective process of representational change, with the reduction of the symbolical importance of death and a more positive assimilation of co-existence with the disease.

In relation to the present research's findings regarding the dimension of fear, the nursing care for clients with HIV/AIDS takes on peculiar characteristics, either because of its consequences linked to stigmatization or because of fear of contagion. One analysis of proxemic communication between the nursing team and these clients in the hospital setting determined that the presence of touch occurred markedly due to technical interventions, with greater distancing predominating on other occasions ${ }^{(22)}$

Thus, understanding of the process of discursive production in social representation on AIDS would also be possible through the lens of the dynamic of the unveiling/masking of images, information and attitudes in the representations linked to social normativity. It would consist therefore of an additional analytical plan for dealing with the issue indicated by studies addressing the dichotomy of information/knowledge and social practices: whether in the area of care for clients with HIV/AIDS, so as to make it more empathic(6) or in the attempt to influence positively the coexistence with the health issue and compliance with drug treatment ${ }^{(17,23)}$; or in the field of prevention of infection with HIV in professional actions through rational use of protective equipment ${ }^{(6,16)}$, or, even, through condom use during sexual relations ${ }^{(24-25)}$.

\section{Conclusions}

This study was centered on the social representations among nurses about people with HIV/AIDS, based on the perspective of a structural approach. Among the elements identified as probably central in the nurses' social representations in the first phase of the research using free association, treatment for the disease and concern about biosafety in the care of people with HIV/ AIDS presented additional indication for the centrality.

It was observed that, generally speaking, the statements organized on the scale with more positive connotations about people with HIV/AIDS were assumed by the study's subjects to be more characteristic, and there was an attribution of lesser importance or refutation of those with a more negative character. These aspects permit the nurses included in the study to think in a social representation with a configuration of more positive attitudes about carriers of HIV/AIDS or, on the other hand, with the possibility of establishing a link with the process of management of impressions, in the social desirability.

The results evidenced for the elements with more markedly contranormative characters, such as the association of carriers of the disease with homosexuality and with the sensation of fear, permit thinking about the constitution of a process of masking in the social representation studied. In this way, it was possible to understand some lags observed among the subjects' discourses and their care practices in relation to the health issue, often grounded in the logic of the concept of risk and not vulnerability, which presupposes more complex articulations in the process of prevention of the disease and care for the persons who have it.

Finally, it is stressed that the concept of mute zone is too recent to be completely controlled and verified. In this way, it contributed to this field of research, showing later deepening of the area to be necessary. This, above all, for the field of psychosocial studies of HIV/AIDS, with wide influence of social normativity.

\section{References}

1. Joint United Nations Programme on HIV/AIDS (UNAIDS). Global report: UNAIDS report on the global AIDS epidemic - 2010. 2010. [acesso 10 jul 2011]. Disponível em: http://www.unaids.org/globalreport/ documents/20101123_GlobalReport_full_en.pdf

2. Ministério da Saúde (BR). Secretaria de Vigilância em Saúde. Departamento de DST, Aids e Hepatites Virais. Boletim Epidemiológico - AIDS e DST - 2010. 2010. 
[acesso 9 jul 2011]. Disponível em: http://www.aids.gov. br/sites/default/files/anexos/publicacao/2010/45974/ boletim_2010_pdf_14544.pdf

3. Apostolidis T, Dany L. Représentations sociales et risques sanitaires: perspectives sociognitives. $\mathrm{R}$ Tempus Actas Saúde Col. 2012;6(3):35-50.

4. Sontag S. Doença como metáfora, AIDS e suas metáforas. São Paulo: Companhia das Letras; 2007. $168 \mathrm{p}$.

5. Oliveira DC, Erdman AL, Giami A, Vargens OMC, Oliveira SA, Gomes AMT, et al. Representações e memória profissional da AIDS de enfermeiras no Brasil: estudo bicêntrico Rio de Janeiro/Florianópolis. Psicol Teor Prat. 2007;9(1):114-8.

6. Formozo GA, Oliveira, DC. Auto-proteção profissional e cuidado de enfermagem ao paciente soropositivo ao HIV: duas facetas de uma representação. Acta Paul Enferm. 2009;22(4):392-8.

7. Jodelet D. Representações Sociais: um domínio em expansão. In: Jodelet $D$, organizador. As representações sociais. Rio de Janeiro (RJ): EdUERJ; 2001. p. 17-44.

8. Jodelet $D$. Le mouvement de retour vers le sujet et I'approche des représentations sociales. Connexions. 2008; 89:25-46.

9. Doise W. Atitudes e representações sociais. In: Jodelet $D$, organizador. As representações sociais. Rio de Janeiro (RJ): EdUERJ; 2001. p. 187-203.

10. Abric J-C. La recherche du noyau central et la zone muette des représentations sociales. In: Abric J-C, organizador. Méthodes d'études des représentations sociales. Paris (FR): Érès; 2003. p. 60-80.

11. Pianelli C, Abric J-C, Saad F. Rôle des représentations sociales préexistantes dans les processus d'ancrage et de structuration d'une nouvelle représentation. CIPS. 2010;86:241-74.

12. Oliveira DC, Costa TL. A zona muda das representações sociais sobre o portador de HIV/ AIDS: elementos normativos e contranormativos do pensamento social. Psicol Teor Prat. 2007;9(2):73-91.

13. Costa TL, Oliveira DC, Formozo GA. Representações sociais sobre pessoas com HIV/Aids entre enfermeiros: uma análise estrutural e de zona muda. Estudos Pesqui Psicol. 2012;12(1):242-59.

14. Flament C, Milland L. La substitution dans les études des représentations sociales: quel processus impliqué? Psychol Fr. 2010;55(3):195-210.

15. Silveira EAA, Carvalho AMP. Suporte relacionado ao cuidado em saúde ao doente com aids: o modelo de comboio e a enfermagem. Rev Esc Enferm USP. 2011;45(3):645-50.

16. Souza MCMR, Freitas MIF. Representações de profissionais da atenção primária sobre o risco ocupacional de infecção pelo HIV. Rev. Latino-Am. Enfermagem. 2010;18(4):748-54.

17. Gomes AMT, Silva EMP, Oliveira DC. Social representations of AIDS and their quotidian interfaces for people living with HIV. Rev. Latino-Am. Enfermagem. 2011;19(3):485-92.

18. Goffman E. Estigma: notas sobre manipulação de identidade deteriorada. 4.ed. Rio de Janeiro: LTC; 2008. $158 \mathrm{p}$.

19. Rutledge SE, Whyte J, Abell N, Brown KM, Cesnales NI. Measuring stigma among health care and social service providers: the HIV/Aids provider stigma inventory. AIDS Patient Care STDs. 2011;25(11):673-82.

20. Rateau P. Les representations sociales. In: Pétard J-P. Psychologie sociale. 2.ed. Paris: Editions Bréal; 2007. p. 164-219.

21. Marques SC, Oliveira DC, Francisco MTR. Abordagem estrutural das representações sociais sobre a aids entre os servidores de um hospital universitário. Esc Anna Nery. 2003;7(2):186-95.

22. Galvão MTG, Paiva SS, Sawada NO, Pagliuca LMF. Analysis of proxemic communication with HIV/AIDS patients. Rev. Latino-Am. Enfermagem. 2006;14(4):491-6. 23. Kourrouski MFC, Lima RAG. Treatment adherence: the experience of adolescents with HIV/AIDS. Rev. LatinoAm. Enfermagem. 2009;17(6):947-52.

24. Ministério da Saúde (BR). Pesquisa de Conhecimentos, Atitudes e Práticas da População Brasileira de 15 a 64 anos de idade. [Internet]. Brasília (Brasil): Programa Nacional de DST e Aids; 2009. [acesso 2 out 2012]. Disponível em: http://www.aids.gov.br/sites/default/ files/anexos/publicacao/2009/40352/pcap_2008_f_ pdf_13227.pdf

25. Guedes HM, Cabral LOC, Costa MVB, Reis AF, Pereira SG, Oliveira-Ferreira F. Risk behavior for the Human Immunodeficiency virus among motel clients. Rev. Latino-Am. Enfermagem. 2012;20(3):536-42. 